\title{
The comparison of short-term results of marsupialization method in operated patients with acute pilonidal abscess and chronic pilonidal sinus
}

\author{
Alaattin Öztürk D \\ Clinic of General Surgery, Adatıp Hospitals, Istanbul, Turkey
}

\begin{abstract}
Objective: This study aimed to compare the short term results of the marsupialization method for the treatment of patients with acute pilonidal abscess and chronic pilonidal sinus disease treated in single step and to investigate the feasibility of final pilonidal sinus treatment in single step in patients with pilonidal abscess.

Material and Methods: A total of 58 patients who were operated on using the marsupialization method were included in this study. Patients with acute pilonidal abscess were included in Group 1 ( 23 patients) and those with chronic pilonidal sinus disease were included in Group 2 ( 35 patients). Pilonidal sinus was excised as a whole by a vertical elliptic incision, with some surrounding intact tissue. After excision, the wound edges were sutured to the postsacral fascia. Daily dressings were performed by relatives at home. The patients were instructed to visit the hospital for follow-up 1-2 times a week. Student's t-test was used to compare the parameters between the groups.

Results: The mean wound length was 73.4 and $61.7 \mathrm{~mm}$ in Group 1 and Group 2, respectively. The mean duration of wound closure was 59.3 and 54.1 days in Group 1 and Group 2, respectively. There was no significant difference between the groups in terms of age, operation time, hospital stay, and duration of wound closure; however, wound length was significantly shorter in Group 2 than in Group 1.

Conclusion: The definitive treatment of acute pilonidal abscess can be achieved in single step by using marsupialization method as well as in patients with chronic pilonidal disease.
\end{abstract}

Keywords: Pilonidal sinus, pilonidal abscess, marsupialization

Cite this article as: Öztürk A. The comparison of shortterm results of marsupialization method in operated patients with acute pilonidal abscess and chronic pilonidal sinus. Turk J Surg 2021; 37 (4): 307-312.

Corresponding Author

Alaattin Öztürk

E-mail:aloz1969@yahoo.com

Received: 23.03 .2021

Accepted: 06.10.202

Available Online Date: 31.12 .2021

○ Copyright 2021 by Turkish Surgical Society Available online at www.turkjsurg.com

DOI: 10.47717/turkjsurg.2021.5002

\section{INTRODUCTION}

Pilonidal sinus is a chronic disease seen mostly in the sacral region of young men and manifests with pits and discharges. Pilonidal sinus disease can be acute or chronic. Patients with chronic disease complain of swelling and discharge in the sacral region, whereas those with acute disease exhibit infection and/or abscess. In the conventional treatment of acute pilonidal abscess, the abscess is drained first, and then the disease is treated with a definitive surgery within 1-2 months after drainage of the abscess (1). However, after simple drainage, chronic pilonidal disease develops in 16-92.5\% of the patients and requires surgical treatment (1-3).

For treating acute pilonidal abscess, initial drainage of the abscess and the subsequent definitive surgery are two separate procedures, resulting in loss of time and labor as well as an increase in costs. The tendency to perform less invasive and less aggressive methods in the treatment of pilonidal disease is increasing $(4,5)$. Therefore, in patients with abscesses, combining both the treatment of acute disease and the concomitant definitive treatment may save time, cost, and labor.

A previous retrospective study has found that drainage and marsupialization can be used to successfully treat pilonidal abscess (6-9); however, further studies on this topic that will change the surgeons' approach toward the treatment of the disease may be needed. In the present study, we compared the short-term results of patients with acute pilonidal abscess and chronic pilonidal sinus disease treated with the marsupialization method in a single session and investigated the feasibility of definitive pilonidal sinus treatment in a single session in patients with pilonidal abscess. 


\section{MATERIAL and METHODS}

A total of 58 patients who underwent marsupialization at our hospital were included in this prospective study. Patients with acute pilonidal abscess were included in Group 1 (23 patients) and those with chronic pilonidal sinus disease were included in Group 2 (35 patients). Patients' age, operation time, hospital stay, wound length, and healing time were recorded. The results of the two groups were compared postoperatively.

\section{Patient Selection}

Patients treated for chronic pilonidal sinus and acute pilonidal abscess with the excision and marsupialization method were included in this study. Ethics committee approval was obtained for the study. Patients were informed about the surgical method as well as postoperative care, and their written consent was obtained for the study. Whether the disease was primary or recurrent was not an inclusion criterion for the study. Patients treated with methods other than marsupialization and patients who discontinued follow-up without completing the healing period were excluded from the study.

\section{Surgical Method}

Patients underwent surgery under general anesthesia. Patients with abscesses were administered antibiotics (single-dose intravenous Cefazolin 1g) 30 min preoperatively, whereas no antibiotics were administered to patients with chronic pilonidal sinus. Patients were laid on the operating table in prone position, and the hips were not stretched with a plaster to allow minimal tissue excision (Figure 1). Pilonidal sinus was excised as a whole by a vertical elliptic incision, while keeping some surrounding tissue intact. In patients with abscesses, excision was performed without a separate abscess drainage (Figure 2). After excision, hemostasis was performed, wound edges were sutured to the postsacral fascia with Prolene suture, and wound defect was minimized (Figure 3). Bupivacaine (Injection Marcaine 0.5\%

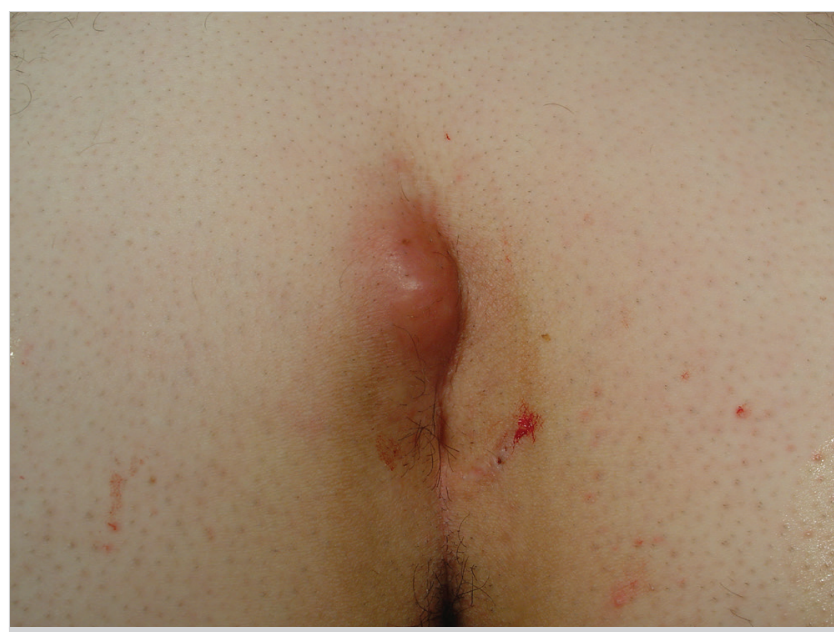

Figure 1. The appearance of pilonidal abscess in the prone position without stretching the buttocks.

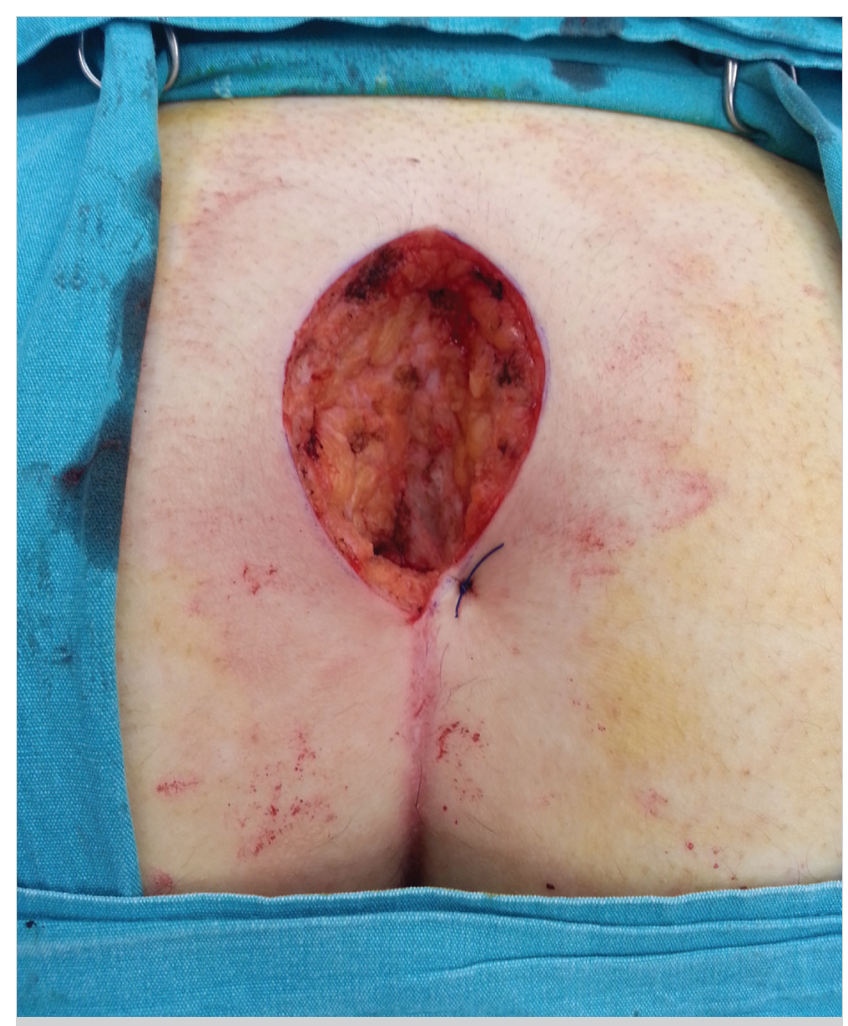

Figure 2. The appearance of the wound after excision.

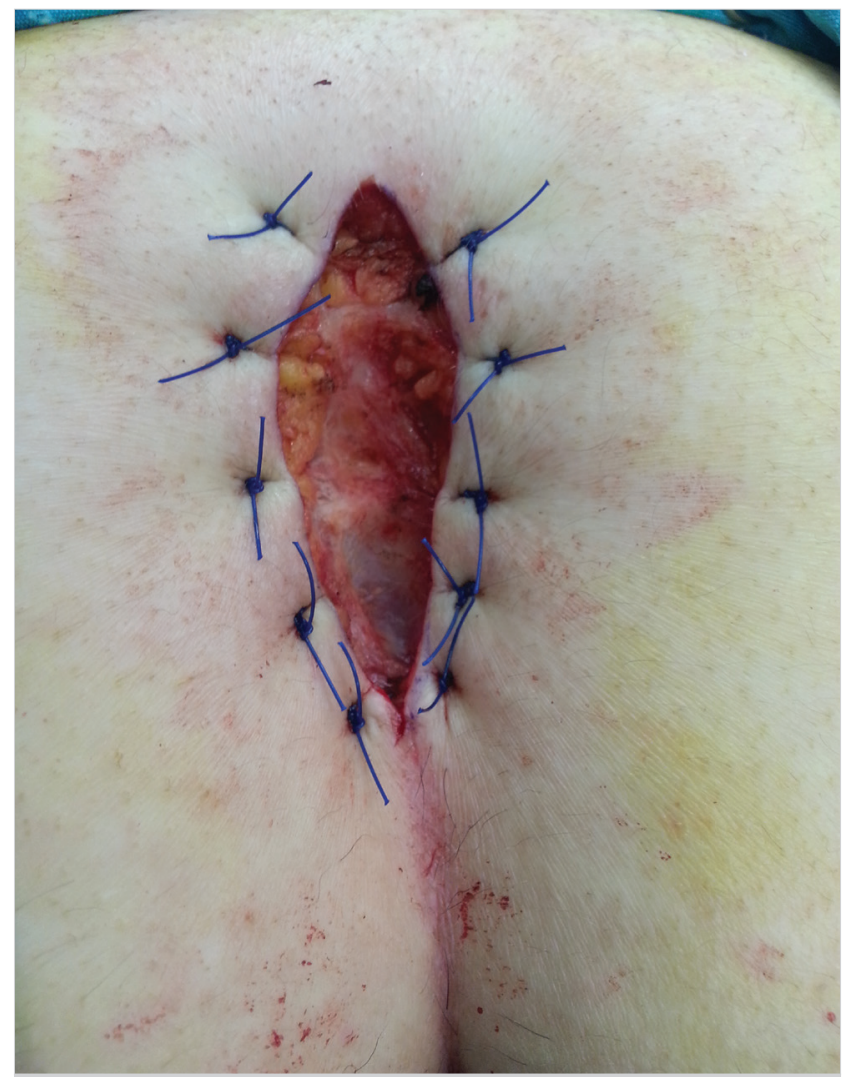

Figure 3. The appearance of the wound after marsupialization is complete. 
Table 1. Comparison of results of the patient groups

\begin{tabular}{|c|c|c|c|}
\hline & Group 1 (n: 23) & Group 2 (n: 35) & $\mathrm{p}$ \\
\hline Age (year) & $28.5(18-41)$ & $26.8(14-47)$ & 0.184 \\
\hline Operation time (min.) & $26.7(10-45)$ & $25.5(15-40)$ & 0.284 \\
\hline Wound length (mm) & $73.4(45-100)$ & $61.7(10-110)$ & 0.029 \\
\hline Period of hospital stay (hour) & $22.2(8-24)$ & $21.6(4-72)$ & 0.395 \\
\hline Period of wound closure (day) & $59.3(28-123)$ & $54.1(20-140)$ & 0.230 \\
\hline
\end{tabular}

solution; AstraZeneca, Türkiye Illaç Sanayi ve Ticaret Ltd. Şti.) was applied to the wound edges. At the end of the procedure, the length of the wound was measured and recorded; and as the hips were not fixed, the width of the wound was not considered a criterion. Excised tissues were sent for pathological examination. Antibiotic therapy was not administered after surgery.

In the marsupialization method described in previous studies, the anterior wall of the pilonidal cyst is excised with the skin, the inside of the cyst is cleansed, and the posterior wall is sutured to the skin $(7,10)$. In our method, the pilonidal cyst was completely excised without leaving any walls, and the skin was sutured to the postsacral fascia.

\section{Patient Follow-Up}

Patients were discharged the day after surgery, and daily dressings were applied by relatives at home. The patients were instructed to visit the hospital for follow-up 1-2 times a week. They returned to work after 7-10 days of rest. During the rest period, only sitting restriction was instructed; there were no restrictions on toilet and bathroom use as well as on walking and sleeping. Early wound dehiscence occurred in three patients in each group (13\% in Group 1 and 8.5\% in Group 2) after wound epithelialization. These wounds also healed with redressing; the period after second dressing was added to the healing time of the patients. Sutures were removed between days 12-15. Dressings were continued until the wound was completely healed. The healing time was determined as the number of days after surgery until the wound was completely healed, there was no need for dressing, and epithelialization was completed. The complications observed and wound healing problems were recorded.

Patients were prescribed analgesics during the postoperative period as needed. When discharged, they were given oral painkillers and topical painkillers for use in dressing.

Long term patient follow-up was not performed after wound healing since it was beyond the aim of this study.

\section{Statistical Analysis}

Student's t-test was used to compare the parameters between the groups. P-value of $<0.05$ was considered significant.

\section{RESULTS}

A total of 58 patients (23 in Group 1 and 35 in Group 2) were included in the study. All patients were male, except for one female patient in Group 1. Mean age was 28.5 and 26.8 years in Group 1 and Group 2, respectively $(p=0.184)$. Mean operation time was 26.7 and 25.5 min in Group 1 and Group 2, respectively $(p=0.284)$. Mean wound length was 73.4 and $61.7 \mathrm{~mm}$ in Group 1 and Group 2, respectively $(p=0.029)$. Mean period of hospital stay was 22.2 and $21.6 \mathrm{~h}$ in Group 1 and Group 2, respectively $(p=0.395)$. Mean duration of wound closure was 59.3 and 54.1 days in Group 1 and Group 2, respectively $(p=0.230)$.

All patients were followed-up until their wounds had completely healed. During this period, no patient developed chronic piIonidal sinus disease. In a patient in Group 1, allergic dermatitis developed on the skin, and the patient was treated in consultation with a dermatologist. Wound dehiscence occurred in three patients in each group following initial closure, daily dressing was re-applied to these patients, and the wounds were healed.

There was no statistically significant difference between the groups in terms of age, operation time, duration of hospital stay, and duration of wound closure; however, wound length was significantly shorter in Group 2 than in Group $1(p=0.029)$ (Table 1).

\section{DISCUSSION}

Although pilonidal sinus disease is often considered a chronic disease with discharge, 30\% of the patients may be hospitalized for acute disease with inflammation and/or abscess. Methods of surgical treatment for chronic disease are numerous, and there is enough time for these to be performed. However, in case of acute disease, treatment options are fewer, and treatment should be immediately provided.

Different methods of treatment have been utilized for acute pilonidal abscess: incision and drainage, aspiration, unroofing-curettage, drainage and negative pressure wound therapy, and partial primary closure (11-16).

Acute pilonidal abscess can be treated sufficiently with incision and drainage. Moreover, it can be performed even in office settings under local anesthesia. Patients' complaints are resolved 
in a short time, and they recover. However, previous studies have reported that the incision and drainage process results in relapse or development of chronic disease in $21 \%-70 \%$ of cases $(11,16-20)$. Moreover, recurrence rates increase with the increase in follow-up period (21).

After pilonidal sinus excision, leaving the wound to secondary recovery results in a longer healing period than using wound closure methods; however, recurrence rates are lower $(22,23)$. The marsupialization method has a short operation time, shorter return-to-work time, lesser pain, fewer complications, and lower recurrence rates $(6,24,25)$; however, the recovery period is longer than other closure methods (26). In a Cochrane review, recurrence rates have been found lower in surgeries that were left open than in other closure methods (27). During the follow-up period in our study, recurrence or transformation into chronic disease was not observed in any of the patients.

In a study in which the marsupialization method was performed for pilonidal abscesses, it has been reported that $95 \%$ of the patients showed improvement in 3-10 weeks, 52\% developed chronic disease, and 15\% had recurrence during follow-up $(7,8)$. In another study, the results of early surgery (unroofing-curettage) and elective surgery (Karydakis flap technique) of pilonidal abscesses have been compared, and healing time has been found shorter in the Karydakis group (28). In a study in which pilonidal abscesses were included, it has been reported that healing time was 32 days in the group that underwent only incision-drainage and secondary recovery, whereas it was 10 days in the group that underwent delayed excision and primary closure after incision and drainage (29). In our study, wound healing period was 59.3 days in Group 1 and 54.1 days in Group 2, and there was no difference between the groups. This healing period is consistent with the period determined in other studies. However, with close follow-up of patients and meticulous dressing, wound healing can be quickly achieved.

The most significant disadvantage of secondary recovery is delayed return to daily life. However, this is the case in all surgical methods requiring incision. Moreover, this period is limited to 7-10 days, after which all daily activities can be performed even if the dressings are continued.

In the case of infected pilonidal sinus disease, some surgeons prefer treating the infection and draining the abscess first, followed by definitive surgery. This is because treating the infection first provides a favorable environment for primary closure or flap surgeries. However, performing a single-session surgery using the marsupialization method can save time and cost. In a previous study on this topic, the disease was successfully treated in $81 \%$ of the patients (8).

In patients with pilonidal abscess, there may be concerns that the excision area will be larger than necessary, and therefore, wound healing period will be longer. According to our results, wound length was longer in patients with pilonidal abscesses (Group 1) when the marsupialization method was used; however, there was no difference between the durations of wound closure.

Drainage followed by definitive surgery on pilonidal sinus abscess is an accepted method. However, during this waiting period, some patients may experience recurrence of the abscess or develop chronic disease. To avoid these complications and reduce costs and labor loss, surgery can be performed in one session.

\section{CONCLUSION}

Marsupialization method can be used safely and effectively in patients with pilonidal abscess as well as in patients with chronic pilonidal disease. However, wound length is slightly shorter in patients with chronic pilonidal.

In patients with pilonidal abscesses, the definitive treatment of the disease can be achieved in one step. Acute pilonidal abscess can be treated using the marsupialization method without causing a larger wound and without a longer healing period.

(The values are mean with minimum and maximum).

Ethics Committee Approval: This study approval was obtained from Fatih University Faculty of Medicine Hospital Ethical Evaulation Committee (Decision No: 207, Date: 05.08.2014)

Peer-review: Externally peer-reviewed.

Author Contributions: Author Contributions: Concept - A.Ö.; Design A.Ö.; Supervision - A.Ö.; Materials - A.Ö.; Data Collection and/or Processing - A.Ö.; Analysis and/or Interpretation - A.Ö.; Literature Search - A.Ö.; Writing Manuscript - A.Ö.; Critical Reviews - A.Ö.

Conflict of Interest: The authors have no conflicts of interest to declare.

Financial Disclosure: The authors declared that this study has received no financial support.

\section{REFERENCES}

1. YIldirim D, Sunamak O, Pergel A, Mounla M. Combined single step definitive treatment in acute pilonidal sinus abscess running head: single step treatment of pilonidal abscess. Surgical Science 2010; 1: 24-6. CrossRef

2. Abramson DJ. Simple marsupialization technic for treatment of pilonidal sinus: Iong-term follow up. Ann Surg 1960; 151(2): 261-7. CrossRef]

3. Watters N, Macdonald IB. Marsupialization of pilonidal sinus and abscess: a report of 50 cases. Can Med Assoc J 1958; 79(4): 236-40. [CrossRef]

4. Vahedian J, Nabavizadeh F, Nakhaee N, Vahedian M, Sadeghpour A. Comparison between drainage and curettage in the treatment of acute pilonidal abscess. Saudi Med J 2005; 26(4): 553-5. [CrossRef]

5. Lasithiotakis K, Aghahoseini A, Volanaki D, Peter M, Alexander D. Aspiration for acute pilonidal abscess-a cohort study. J Surg Res 2018; 223: 123-7. CrossRef 
6. Khalil PN, Brand D, Siebeck M, Hallfeldt K, Mutschler W, Kanz KG. Aspiration and injection-based technique for incision and drainage of a sacrococcygeal pilonidal abscess. Emerg Med 2009; 36(1): 60-3. [CrossRef]

7. Kepenekci I, Demirkan A, Celasin H, Gecim IE. Unroofing and curettage for the treatment of acute and chronic pilonidal disease. World J Surg 2010; 34(1): 153-7. [CrossRef]

8. Kanat BH, Girgin M, IIhan YS, Aksu A. Effects of the Nanova ${ }^{\mathrm{TM}}$ therapy system in unroofing-curettage and secondary intention healing of piIonidal abscesses. Turk J Colorectal Dis 2017; 27(3): 89-93. [CrossRef]

9. Lasheen A, Safwat K, Morsy M, Fiad A, Elmoregy A. Excision and partial primary closure of wound for pilonidal disease. Surgical Science 2012; 3: 366-70. [CrossRef]

10. Jensen SL, Harling H. Prognosis after simple incision and drainage for a first-episode acute pilonidal abscess. Br J Surg 1988; 75(1): 60-1. [CrossRef]

11. Eryilmaz R, Sahin M, Alimoglu O, Kaya B. The comparison of incision and drainage with skin excision and curettage in the treatment of acute pilonidal abscess. Ulus Travma Derg 2003; 9(2): 120-3. LCrossRef]

12. Matter I, Kunin J, Schein M, Eldar S. Total excision versus nonresectional methods in the treatment of acute and chronic pilonidal disease. Br J Surg 1995; 82(6): 752-3. [CrossRef]

13. Allen-Mersh TG. Pilonidal sinus: finding the right track for treatment. Br J Surg 1990; 77(2): 123-32. [CrossRef]

14. Stauffer VK, Luedi MM, Kauf P, Schmid M, Diekmann M, Wieferich K, et al. Common surgical procedures in pilonidal sinus disease: a metaanalysis, merged data analysis, and comprehensive study on recurrence. Sci Rep 2018; 8(1): 3058. [CrossRef]

15. Sahsamanis G, Samaras S, Mitsopoulos G, Deverakis T, Dimitrakopoulos $G$, Pinialidis D. Semi-closed surgical technique for treatment of pilonidal sinus disease. Ann Med Surg 2017; 15:47-51. [CrossRef]

16. Brasel KJ, Gottesman L, Vasilevsky CA. Members of the evidence-based reviews in surgery group. Meta-analysis comparing healing by primary closure and open healing after surgery for pilonidal sinus. J Am Coll Surg 2010; 211(3): 431-4. [CrossRef]

17. Burney RE. Treatment of pilonidal disease by minimal surgical excision under local anesthesia with healing by secondary intention: Results in over 500 patients. Surgery 2018; 164(6): 1217-22. [CrossRef]

18. Karakayali F, Karagulle E, Karabulut Z, Oksuz E, Moray G, Haberal M. Unroofing and marsupialization vs. rhomboid excision and limberg flap in pilonidal disease: a prospective, randomized, clinical trial. Dis Colon Rectum 2009; 52(3): 496-502. [CrossRef]
19. Gencosmanoglu R, Inceoglu R. Modified lay-open (incision, curettage, partial lateral wall excision and marsupialization) versus total excision with primary closure in the treatment of chronic sacrococcygeal pilonidal sinus: a prospective, randomized clinical trial with a complete two-year follow-up. Int J Colorectal Dis 2005; 20(5): 415-22. [CrossRef]

20. Al-Khamis A, McCallum I, King PM, Bruce J. Healing by primary versus secondary intention after surgical treatment for pilonidal sinus. Cochrane Database Syst Rev 2010; 20(1): CD006213. [CrossRef]

21. Licheri S, Pisano G, Erdas E, Farci S, Pomata M, Daniele GM. Radical treatment of acute pilonidal abscess by marsupialization. G Chir 2004; 25(11-12): 414-6. [CrossRef]

22. Kanat BH, Bozan MB, Yazar FM, Yur M, Erol F, Özkan Z, et al. Comparison of early surgery (unroofing-curettage) and elective surgery (Karydakis flap technique) in pilonidal sinus abscess cases. Ulus Travma Acil Cerrahi Derg 2014; 20(5): 366-70. [CrossRef]

23. Sakr MF, Ramadan MA, Hamed HM, Kantoush HE. Secondary healing versus delayed excision and direct closure after incision and drainage of acute pilonidal abscess: a controlled randomized trial. Arch Clin Exp Surg 2012; 1(1): 8-13. [CrossRef]

24. Goodall P. The etiology and treatment of pilonidal sinus: a review of 163 patients. Br J Surg 1961; 49:212-8. [CrossRef]

25. Musella M, Milone M, De Palma GD, Milone F, Sosa Fernandez LM. Minimally invasive pilonidal sinus treatment: a narrative review. Open Med (Wars) 2019; 14:532-6. [CrossRef]

26. Gökbuget ZM, Özcan R, Karagöz A, Tütüncü AÇ, Topuzlu Tekant G. Endoscopic pilonidal sinus treatment (EPSiT) in the pediatric age group: Short-term results. Ulus Travma Acil Cerrahi Derg 2021; 27(4): 443-8. [CrossRef]

27. Matter I, Kunin J, Schein M, et al. Total excision versus non-resectional methods in the treatment of acute and chronic pilonidal disease. Br J Surg 1995; 82(6): 752-3. [CrossRef]

28. Surrell JA. Pilonidal disease. Surg Clin North Am 1994; 74(6): 1309-15. [CrossRef]

29. Cavanagh CR, Schnug GE, Girvin GW, McGonigle DJ. Definitive marsupialization of the acute pilonidal abscess. Am Surg 1970; 36(10): 650-1. [CrossRef] 


\section{ORIJINAL ÇALIŞMA-ÖZET}

Turk J Surg 2021; 37 (4): 307-312

\section{Ameliyat edilen akut pilonidal apse ve kronik pilonidal sinüs hastalarında marsupiyalizyasyon yönteminin erken dönem sonuçlarının karşılaştırılması}

Alaattin Öztürk

Adatıp Hastanesi, Genel Cerrahi Kliniği, İstanbul, Türkiye

\section{ÖZET}

Giriş ve Amaç: Marsupiyalizyasyon yöntemi ile tek seansta tedavi edilen, akut pilonidal apse ile kronik pilonidal sinüs hastalığı olan hastalarda yöntemin erken dönem sonuçlarını karşılaştırmayı ve pilonidal apsesi olan hastaların tek seansta nihai pilonidal sinüs tedavisinin yapılabilirliğini araştırmayı amaçladık.

Gereç ve Yöntem: Marsupiyalizyasyon yöntemi ile ameliyat edilen 58 hasta bu çalışmaya alındı. Akut pilonidal apsesi olan hastalar Grup 1 (23 hasta), kronik pilonidal sinüs hastalığı olanlar Grup 2 (35 hasta) şeklinde ayrıldı. Pilonidal sinüs, vertikal eliptik insizyonla, bir miktar sağlam doku ile bir bütün olarak eksize edildi. Eksizyondan sonra yara kenarları postsakral fasyaya dikildi. Günlük pansumanlarını genellikle evde bir yakını yaptı. Haftada 1-2 kez hastaneye kontrole çağrıldılar. Her iki grup arasında parametrelerin karşılaştırılması için Student T testi kullanıldı.

Bulgular: Yaranın ortalama boyu Grup 1'de $73.4 \mathrm{~mm}$, Grup 2'de $61.7 \mathrm{~mm}$ idi ( $\mathrm{p}=0,029)$. Yaranın ortalama kapanma süresi Grup 1 hastalarında 59.3 gün, Grup 2 hastalarında 54.1 gün idi $(p=0,230)$. Gruplar karşılaştırıldığında, yaş, ameliyat süresi, hastanede kalış süresi ve yaranın kapanma süreleri arasında istatistiksel olarak fark bulunmadı; yara boyu Grup 2 hastalarında istatistiksel olarak anlamlı olarak daha kısa bulundu $(p=0,029)$.

Sonuç: Kronik pilonidal sinüs ameliyatında olduğu gibi akut pilonidal apseli hastalarda da marsupiyalizyasyon yöntemi ile tek seansta hastalığın nihai tedavisi yapılabilir.

Anahtar Kelimeler: Pilonidal sinus, pilonidal apse, marsupiyalizyasyon

Doi: $10.47717 /$ turkjsurg.2021.5002 